edukacji w poszczególnych epokach historycznych (od starożytności po początki XX wieku), że był przeciwnikiem wszelkiego zastoju, dogmatyzmu i schematyzmu w nauczaniu; znał dokonania wybitnych myślicieli i pedagogów polskich i europejskich (Sturm, Ratke, Montaigne, Komeński, Locke, Rousseau, Śniadecki, Pestalozzi, Froebel, Tołstoj, Spencer, Freinet, Decroly, Dawid, Szycówna); przedstawił drobiazgowy, oparty na rzetelnych i realistycznych podstawach program reformy szkoły, określanej przez niego jako „Szkoła Życia”, która miała zastąpić starą „Szkołę śmierci”; potrafił wskazać dobrodziejstwa rewolucji naukowo-technicznej dla edukacji w odniesieniu do metod, treści, celów nauczania; umieścił Dziecko w centrum wszelkich zabiegów pedagogicznych; trafnie diagnozował i prognozował zmiany zachodzące w oświacie i inne. Korczak przestrzegał, aby szkoła jako jedna z najważniejszych instytucji w państwie była reformowana „ostrożnie”, zgodnie z potrzebami społecznymi i bez nacisków politycznych.

Sympozjum zakończono z nadzieją, że uda się zacieśnić współpracę poszczególnych ośrodków akademickich, zajmujących się nauczaniem i badaniami naukowymi w zakresie historii wychowania.

Jacek Kulbaka

\title{
Projekt badawczy historyków wychowania realizowany z Narodowego Programu Rozwoju Humanistyki
}

W gronie finalistów II edycji konkursu na granty Narodowego Programu Rozwoju Humanistyki znalazł się projekt badawczy historyków wychowania zatytułowany „Komisja Edukacji Narodowej model szkoły i obywatela - koncepcje, doświadczenia i inspiracje”. Projekt, którego kierownikiem jest prof. dr hab. Kalina Bartnicka, realizowany jest w Instytucie Historii Nauki PAN im. Ludwika i Aleksandra Birkenmajerów w Warszawie.

W zespole badawczym, powołanym dla realizacji grantu, uczestniczy 18 osób należących do Towarzystwa Historii Edukacji i reprezentujących liczne ośrodki naukowe: IHN PAN, Uniwersytet Warszawski, Uniwersytet im. Adama Mickiewicza w Poznaniu, Uniwersytet Gdański, Uniwersytet Mikołaja Kopernika w Toruniu, Uniwersytet Pedagogiczny im. Komisji Edukacji Narodowej w Krakowie, Uniwersytet Jana Kochanowskiego w Kielcach, Uniwersytet Wrocławski, Wyższą Szkołę Pedagogiczną TWP w Warszawie oraz Wyższą Szkołę Ekonomii i Innowacji w Lublinie. Trzeba podkreślić, że w gronie osób zaangażowanych w wykonanie projektu są zarówno doświadczeni badacze, posiadający bogaty dorobek naukowy, jak i reprezentanci „młodego pokolenia” historyków wychowania ${ }^{1}$.

1 Wśród wykonawców projektu znaleźli się: prof. dr hab. Kalina Bartnicka, prof. dr hab. Irena Szybiak, prof. dr hab. Władysława Szulakiewicz, prof. dr hab. Dorota Żołądź-Strzelczyk, prof. dr hab. Wiesław Jamrożek, prof. dr hab. Adam Massalski, prof. dr hab. Andrzej Meissner, prof. dr hab. Kazimierz Puchowski, dr hab. 
Pomysł podjęcia nowych badań nad Komisją Edukacji Narodowej wiąże się ściśle z przypadającymi w roku 2013 i 2023 obchodami 240- i 250-lecia jej utworzenia. W dokumentach złożonych do konkursu NPRH wnioskodawcy następująco określili ich najważniejsze cele:

Głównym celem naukowym projektu jest zabezpieczenie, opublikowanie i udostęnienie zasobu źródłowego związanego z reformami Komisji i funkcjonowaniem jej agend i szkót, zasobu o fundamentalnym znaczeniu dla dziedzictwa narodowego i kultury narodowej, poddanie weryfikacji dotychczasowych ustaleń, a także nowoczesne (spetniajace wymogi nowoczesnej historiografii i metodologii historii) opracowanie materiatów (które sa rozproszone, trudno dostęne, czesto poza granicami kraju, a niekiedy nie weszły do obiegu naukowego). Projekt przewiduje prace dokumentacyjne, edytorskie i badawcze nad spuścizna Komisji Edukacji Narodowej.

Projekt uwzględnia przygotowanie do druku szeregu wydawnictw w tym bibliografii KEN oraz słownika jej działaczy i nauczycieli, edycję materiałów źródłowych i prac obejmujących działalność szkół Komisji w poszczególnych wydziałach, a także szkół głównych w Krakowie i w Wilnie. Wydawnictwa te ma dodatkowo uzupełnić album oraz film dokumentalny poświęcony Komisji.

Jednocześnie $\mathrm{w}$ trakcie realizacji planów badawczych i wydawniczych przewidziano organizację dwóch konferencji naukowych ${ }^{2}$. Pierwsza z nich ma mieć charakter spotkania inaugurującego 5-letni okres intensywnych badań nad spuścizną Komisji i podsumowującego wyniki dotychczasowych poszukiwań w zakresie tej problematyki. Druga z planowanych konferencji przewidziana jest na końcowy etap realizacji projektu, a zatem na rok 2017. Podczas tego spotkania przewidziano przedstawienie sprawozdań z wykonania wszystkich wyszczególnionych w grancie zadań.

W roku 2013 w Pałacu Staszica w Warszawie odbyły się pierwsze spotkania naukowe osób zaangażowanych w ten projekt. Podczas tych seminariów zapadły ważne decyzje dotyczące harmonogramu prac oraz powołania zespołów koordynujących poszczególne działania badawcze. Utworzono m.in. zespoły: bibliograficzny, biograficzny, archiwalny i źródłowy, zespół do spraw podręczników wydanych przez KEN oraz zespół przygotowujący wystawę dokumentującą działalność Komisji. Jednocześnie ustalono podział zadań w zakresie badań nad funkcjonowaniem szkół KEN - w tym celu powołano zespoły „wydziałowe” (litewski, małopolski, mazowiecki, wielkopolski, wołyński i ukraiński), a także zespół do spraw szkół zakonnych oraz badający działalność Szkół Głównych. Ich

\footnotetext{
Janina Kamińska, dr hab. Agnieszka Wałęga, dr Justyna Gulczyńska, dr Ewa Kula, dr Michał Nowicki, dr Marzena Pękowska, dr Krzysztof Ratajczak, dr Jan Ryś, dr Jolanta Szablicka-Żak, dr Ryszard Ślęczka. Grupę badawczą wspomagają swoim doświadczeniem i konsultacjami w zakresie kwerend archiwalnych oraz przygotowywania bibliografii prof. dr hab. Stefania Walasek (Uniwersytet Wrocławski) oraz prof. dr hab. Julian Dybiec (Uniwersytet Jagielloński).

2 Trzeba zaznaczyć, że w związku z przypadającą w tym roku 240 rocznicą powstania KEN w dniach 14-15 października 2013 r. planowana jest konferencja naukowa Komisja Edukacji Narodowej: ludzie i dzieło w dialogu pokoleń. Jej organizatorami są Instytut Historii i Katedra Historii Oświaty i Wychowania Uniwersytetu Pedagogicznego im. Komisji Edukacji Narodowej w Krakowie oraz Instytut Historii Nauki PAN im. Ludwika i Aleksandra Birkenmajerów w Warszawie (przy współpracy Towarzystwa Historii Edukacji).
} 
zadaniem będzie m.in. prowadzenie poszukiwań w zakresie regionalnej specyfiki poszczególnych placówek edukacyjnych oraz ich odbioru przez społeczności lokalne.

Ważnym elementem dyskusji toczonej podczas owych spotkań były problemy związane z koniecznością przeprowadzenia wielu kwerend archiwalnych i bibliotecznych na terenie Polski oraz za granicą (m.in. na Litwie, Ukrainie, Białorusi, w Rosji: w Moskwie i w Petersburgu, Niemczech i Austrii). Ich celem ma być przede wszystkim scalenie wciąż rozproszonych materiałów dokumentujących prace Komisji i przygotowanie ich kompletnego zestawienia bibliograficznego. W tym kontekście pojawiły się także propozycje podjęcia prac nad ukazaniem Komisji Edukacji Narodowej na tle międzynarodowym i zbadania kwestii recepcji jej działań nie tylko w odniesieniu do XVIII i XIX w., ale i we współczesnej Europie. Zespół dyskutował również nad potrzebą przygotowania przewodnika archiwalnego informującego o dostępnych obecnie źródłach do dziejów KEN (w tym i tych znajdujących się w bibliotecznych zbiorach rękopisów) uwzględniającego jednak i te źródła, które uległy zniszczeniu podczas wojny.

Z problematyką kwerend, przewodników i bibliografii wiązały się bezpośrednio także kwestie przygotowania słownika biograficznego działaczy i nauczycieli Komisji Edukacji Narodowej. Uczestnicy projektu podejmowali takie zagadnienia jak określenie adresatów tego opracowania czy ustalenie wzoru przygotowywanych biogramów. Pojawiły się propozycje uwzględnienia w słowniku członków i współpracowników KEN, generalnych wizytatorów, rektorów i profesorów szkół głównych oraz wydziałowych, wybranych nauczycieli świeckich i zakonnych pracujących w jej szkołach, autorów projektów reform i podręczników szkolnych oraz wybitnych wychowanków instytucji edukacyjnych nadzorowanych przez Komisję.

Jednym z najważniejszych punktów dyskusji była również inaugurująca projekt konferencja. Ustalono, że konferencja ta, połączona z wystawą dokumentującą dorobek Komisji, odbędzie się w dniach 8-9 października 2013 r. w Warszawie w budynku Senatu Rzeczypospolitej Polskiej. Miejsce obrad wybrano nieprzypadkowo - to przecież Parlament powołał do życia Komisję Edukacji Narodowej. Umiejscowienie konferencji w salach Senatu ma dodatkowo podkreślać jej uroczysty i ,,propagandowy” charakter. Głównym celem tego spotkania jest bowiem zainicjowanie dyskusji nad działalnością Komisji. Organizatorzy konferencji przewidzieli 5 wystąpień o charakterze popularnonaukowym, które wygłoszą profesorowie Kalina Bartnicka, Irena Szybiak, Julian Dybiec, Adam Massalski i Michał Śliwa. W związku z tą konferencją organizatorzy przewidują także opublikowanie pamiątkowego folderu. Należy również zaznaczyć, że materiały z wystawy, która zostanie uroczyście otwarta 9 października 2013 r. w czasie posiedzenia Senatu, będą następnie prezentowane na Wydziale Pedagogicznym Uniwersytetu Warszawskiego, a w późniejszym okresie także w innych polskich uczelniach.

Ze względu na zbliżający się termin tej konferencji wiele uwagi poświęcono także okolicznościowej wystawie i albumowi Komisji Edukacji Narodowej. Ich przygotowanie wymaga bowiem czasochłonnych kwerend w Zakładzie Starych Druków i w Gabinecie Rycin Biblioteki Narodowej oraz w zbiorach Archiwum Głównego Akt Dawnych. Przedsięwzięcia te mają ukazywać dotychczasowy stan wiedzy i badań nad szkołami i współpracownikami Komisji dlatego przewidziano zamieszczenie w nich oprócz „tradycyjnych" dokumentów także materiałów kartograficznych i ikonograficznych. 
Dotychczasowe spotkania uczestników projektu, noszące charakter naukowo-sprawozdawczych seminariów, pozwoliły na zaplanowanie głównych kierunków badań nad odtworzeniem modelu szkoły i obywatela stworzonym przez Komisję Edukacji Narodowej. Wyznaczone podczas obrad zespoły badawcze rozpoczęły prace dokumentacyjne i bibliograficzne, ustalono także wstępny harmonogram kwerend archiwalnych i bibliotecznych.

W roku 2013 planowane jest kolejne seminarium, jeszcze w październiku, tuż po zakończeniu obrad „senackiej” konferencji. Uczestnicy projektu zamierzają połączyć to spotkanie z organizacją studyjnej wycieczki po Warszawie pod hasłem: śladami Komisji Edukacji Narodowej.

\section{Agnieszka Wałega}

\section{Sprawozdanie z konferencji}

W dniach 11-14 lipca 2013 r. w Jarosławiu zorganizowana została konferencja pt. „Losy i znaczenie dziedzictwa po klasztorach jezuickich skasowanych na obszarze Rzeczypospolitej Obojga Narodów oraz jego znaczenie dla powstania i działalności Komisji Edukacji Narodowej (w 240. rocznicę kasaty zakonu jezuitów i powstania KEN)”. Obrady otworzył prof. Marek Derwich, gospodarz spotkania, referatem „Projekt 'Dziedzictwo kulturowe po klasztorach skasowanych na ziemiach dawnej Rzeczypospolitej oraz na Śląsku w XVIII i XIX w.: losy, znaczenie, inwentaryzacja"”.

Część właściwą rozpoczęła Magdalena Ujma (Opole), wygłaszając referat dotyczący spuścizny pojezuickiej w Centralnym Państwowym Archiwum Historycznym Ukrainy we Lwowie, otwierając panel dotyczący źródeł do dziejów kasat. Omówione zostały wybrane jednostki archiwalne pod kątem ich zawartości i przydatności do badań w różnym zakresie. Zwrócono przy tej okazji uwagę na znajdujące się tam inwentarze i plany wybranych kolegiów jezuickich. Józef Kus (Lublin) z kolei omówił problematykę akt pojezuickich w Archiwum Państwowym w Lublinie, w zakresie losu materiałów źródłowych po kasacie zakonu jezuitów, przemieszczania ich oraz zawartości zespołu archiwalnego, zawierającego siedem jednostek archiwalnych, związanych z dziejami dawnego kolegium. Poszczególne jednostki zostały następnie dosyć szczegółowo omówione. Kolejny referent, Waldemar Rozynkowski (Toruń), wskazywał na wartość niedawno utworzonego Archiwum Diecezjalnego w Toruniu. Omówił on w bardzo ogólnym zarysie dzieje kolegium toruńskiego i na zakończenie zaprezentował źródło „Inwentarz ‘Rzeczy Kościelnych’ Kolegium Jezuickiego w Toruniu z 1773 r.” Wojciech Zawadzki (Warszawa), podkreślając rozwój sieci szkół jezuickich w Polsce, skoncentrował się na szkole malborskiej w okresie 1618-1780, z uwzględnieniem problemów lokalowych i ogólnej historii zakonu w tym miejscu, aż do czasu po kasacie. Jak zaznaczył referent, jego przemówienie było pokło- 